\title{
Regional Economic Cooperation
}

Gordon M. Gough, (Email: gordongough@hotmail.com), Ashland University

Sivakumar Venkataramany, (Email: svenkata@ashland.edu), Ashland University

\begin{abstract}
Free trade agreements are an essential segment of the global economy. Regional economic cooperation is the fuel firing the push towards a global economy. Nations will need to belong to some type of regional economic cooperation unit to compete with other regionally aligned nations. This article provides three factors (1) an overview of the qualifications that exist regarding FTA's, (2) comparison of the four largest FTA's (EU, NAFTA, MERCOSUR, and ASEAN), and (3) FTA's effect on global foreign policy. These factors demonstrate the vitality of a regional future.
\end{abstract}

\section{INTRODUCTION}

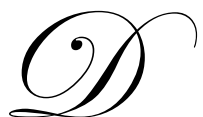

ifferent forms of trade have been in existence for thousands of years. Whether or not you are analyzing the trade routes of antiquity or modern times, trade and commerce have played a vital role in business expansion. Modern times have witnessed the birth of a global economy. Countries today engage in some form of global trade. Although, the United States has led the world in the new global economy, many countries are finding value in grouping together to form a regional free trade bloc or alliance. Two well know trade blocs are the European Union (EU) and the North American Free Trade Agreement. These two blocs are creating huge spheres of influence for their member countries.

Regional trading blocs provide countries with the ability to exchange goods with member countries with minimal or no tariffs or cumbersome trade regulations. The EU, primarily Germany and France spearheaded the joint economies and currency movements between Western and Central European countries. This has allowed the EU to further formalize and strengthen trade between members, non-members, or trade blocs. With united economies and currency, the EU is establishing itself as a dominant trade bloc.

Although, the EU and NAFTA are older more established Free Trade Agreements (FTA's), many other regional blocs are imitating their structures and purpose. The Association of East Asian Nations (ASEAN) and the Common Market of the South (MERCOSUR) whose members are not solitary economic powerhouses have forged together with other developing nation-states in hope of creating a successful regional trade bloc. This phenomenon is happening all over the world. Every continent beside Antarctica has been affected by this concept. Three factors used to study the movement of nation-states towards some form of regional trade arrangement are: (1) what defines or qualifies a free trade agreement, (2) comparison of current and proposed FTA's, and (3) the resulting impact that FTA's play on foreign policy. These three steps illustrate the basis for FTA existence.

\section{DEFINITION AND QUALIFICATIONS OF A REGIONAL TRADE BLOC}

Free Trade Agreements and their likeness began shortly after World War II. Although, some would argue that FTA's could be linked to Woodrow Wilson's unfortunate failure of the United Nation's parent organization, the League of Nations. Beginning with the Industrial Revolution the world has been slowly moving towards a global economy. Many of the precursors to World War II were created due to an economic reliance between the United States - the lender, the United Kingdom - the borrower, and Germany - the payee. This triangle of economies led to the Great Depression, which many believe was an indirect cause of World War II

After World War II, the United States emerged as a superpower with excellent resources and a stable and developed economy. The US after WWII developed a rebuilding model for post war Western and Central Europe better known as the Marshall Plan. The Marshall Plan was named after United State Secretary of State George C. 
Marshall. His plan led to the regional economic cooperation between Central and Western European countries. The United States offered up to $\$ 20$ billion for relief, but only if the European nations could get together and draw up a rational plan on how they would use the aid. For the first time, they would have to act as a single economic unit; they would have to cooperate with each other. Marshall also offered aid to the Soviet Union and its allies in Eastern Europe, but Stalin denounced the program as a trick and refused to participate. The Russian rejection probably made passage of the measure through Congress possible. The philosophy outlined by the Marshall Plan is the beginning of modern day regionalism and globalization.

The end of World War II created an environment suited for an expansion in the world economy. The creation of the General Agreement on Tariffs and Trade (GATT) accelerated multilateral trade. In postwar years the pace of globalization was quickened by the multilateral trade negotiations of the General Agreement of Tariffs and Trade (GATT); the liberalization of trade and investment; and the deregulation and privatization of national industries (Urata, 2002). GATT played a decisive role in the creation of FTA's or Regional Trade Agreements (RTA's). Through the unitary principles of GATT, states were allowed to trade with other states utilizing one set of rules or directives. Upon its creation in 1948, states have lowered or eliminated tariffs and import fees. This has helped spawn the creation of the global economy. Since the GATT was implemented in 1948 there have been eight "rounds" of global trade talks, each involving more countries, and taking liberalisation further, than the last (Fifty years on, 1998). These global trade talks ultimately created the World Trade Organization (WTO), which rigidly regulates trade conflicts and disputes. Unlike, its predecessor GATT, the WTO is a stable organization with an agreed upon power to firmly regulate global commerce and trade. The World Trade Organization (WTO) is the only international organization dealing with the global rules of trade between nations. Its main function is to ensure that trade flows as smoothly, predictably and freely as possible (www.wto.org, 2005). The WTO currently has 148 members, and its primary role is to harness the world's commerce. The WTO, which is an autonomous body, was created per the Uruguay round of talks in 1993. Although, the WTO is free of direct control by any nation-state, changes in its rules and regulations must be approved by members' respected parliamentary processes. Virtually all decisions in the WTO are taken by consensus among all member countries and they are ratified by members' parliaments (www.wto.org, 2005). Without the fear of direct oversight, the WTO can operate as developer of freer global trade.

Free Trade Agreements were primarily formed to increase trade between neighboring countries. Regional Economic Cooperation has many different levels of participation. The reference below showcases a theory behind regional integration. One well-recognized method for classifying the different types of regional integration is to categorize them by their stage of development, a method which focuses on the degree of integration, which is the one adopted here. From order of looser to stronger integration, there are: (1) FTAs, which remove tariffs and quotas within the group; (2) Custom unions, which establish common tariffs for countries outside this group; (3) Common markets, which lift restrictions on the movements of factors of production within the region; and (4) Economic unions, in which common macroeconomic policies are adopted (Urata, 2002). The analysis of this theory would prove that FTA's are the foundation for nation-states to formalize a sense of regional cooperation. FTA's have the ability to homogenize regional attributes and lessen regional economic threats. By members having a sense of cooperation, intra and inter regional trade can promote growth within states and between states. This expands the importance of the particular region. In many cases, regional trade blocs are bands of smaller countries whose individual trade would be minuscule to the economies of nations or other RTA's similar to United States and the European Union. However, the affiliation affords them greater opportunities than they could possibly acquire as individual nation states. The United States, a former naysayer, is beginning to see the advantages of regional integration by joining FTA's.

Why this sudden push towards regional integration? I believe the creation of a unified Europe has created a need for regional cooperation, especially, in developing regions similar to Latin and South America. The EU has created an urgency to regionalize. The EU's members are beginning to take a lion's share of world exports and imports far surpassing the United States. If nations-states fail to form productive regional alliances, other regional cooperation's will dictate world commerce. Moreover regional alliances can promote regional products native to only that region's part of the world. Nation-states can use the RTA to effectively promote current markets or create new ones. 
There are several internal and external reasons why there is this sudden surge to form FTA's. External factors include securing markets and providing export opportunities for domestic companies by dismantling the trade barriers between participating countries (Urata, 2002). With the expansion of production, nation-states participating in the FTA are allowing themselves to increase their exporting, thus creating stronger home markets. Successful FTA's have created a rapidly moving trend toward the creation of regional trade agreements. Many nation-states feel compelled to join a FTA for fear of not being included or being at a comparative disadvantage with other nation-state that are members of a FTA. This cycle in itself is creating the environmental push towards regionalization.

Internal factors pressing nation-states towards regional trade bloc membership are positive indicators in economic growth through increased efficiency from competition (Urata, 2002). The lack of competition can allow companies to become lethargic or ant-competitive, which can slow the growth of an economy. Since the 1970's, policymaker's have come to recognize the benefits of liberalization of foreign trade and investment, deregulation and the removal of domestic regulations have facilitated high economic growth in the developing countries of East Asia, as well as industrial nations such as the US and the UK (Urata, 2002). The efficiency of markets pushes many nationstates to form or join regional trade agreements. The regional cooperation provides new options for economic expansion of domestic products. The market based economy will wean out the weaker companies and elevate the efficient companies. FTA's have allowed many nations-states to liberalize their foreign trade and investment.

Customs unions are a stronger form of regional cooperation that is based on inter-regional cooperation with nation-states or other RTA's. Take for instance the Gulf Cooperation Council, which is composed of the following Persian Gulf nation-states; Bahrain, Kuwait, Oman, Qatar, Saudi Arabia, and the United Arab Emirates. The Customs Union is a big step forward in promoting trade and investment among the member states of the Council. The Customs Union is a single customs zone with a unified customs tariff of $5 \%$ on GIF value subject to certain exceptions (Matthews \& Issa, 2003). Customs unions provide the cooperating nation-states the advantage of intra and inter regional trading. The members can share the benefits within their trade bloc, or collectively with larger nation-states or other RTAs.

Customs unions differ from FTA's, because customs unions provide methods of trade as a whole regional bloc rather than just within a regional bloc. Customs union members enjoy trade within the union, and the greater capacity of trade as a union with either larger countries, such as the United States, or regional trade blocs similar to NAFTA. Customs unions tend to be truly regional. Many FTA's will have global partners; however, customs unions rely primarily on neighbors with close proximity.

Economic unions are the strongest form of regional economic cooperation. The European Union is a perfect example of what an economic union would resemble. An economic union has all the characteristics of an FTA and a common market; however, it goes a bit farther with additional macro-economic principles, such as a unified currency. The European Union established this January 1, 2002. Although, having a unified currency is not the only prerequisite or condition required of an economic union, but it is one of extreme importance. FTAs provide nationstates with the ability to increase foreign direct investment and their economical output through mutually beneficial RTA's. As mentioned previously in this paper, RTA's are categorized by the amount of power the trade bloc may have over its member nations. FTA's are simply free trade zones, which have the ability to increase trade among nations with fewer or less regulations.

Furthermore, FTAs provide a sound alternative to multilateral trade under the WTO. The WTO has been under immense scrutiny by various groups protesting its existence. However, FTA's are a viable substitute. One particular reason why nation-states prefer the structure of FTA's over the WTO's multilateral trade is the size and amount of participants. Third, another reason why countries are opting for FTAs is related to the size of membership as FTAs involve fewer participants. It is also much easier under a FTA to establish rules from new issues that are not yet under discussion in the WTO (Urata, 2002). FTA's are a potential format, which will allow for global trade without tariffs and cumbersome regulations. However, regional economic cooperation must begin as a FTA and gradually move to an economically stronger regional trade agreement, such as, an economic union. Following the path of regional economic evolution, the WTO will eventually be afforded many of the needed global trade polices that will enhance global commerce. 


\section{CURRENT AND PROPOSED REGIONAL TRADE BLOCS}

Regional Trade Agreements as outlined earlier serve various purposes, which include access to the global economy; currency stabilization; and economic strength through mutual relationships with RTA participants. It appears that the 1990's witnessed a boom in FTA organization. Nation-states were forming some form of regional trade with neighbors and allies. By the end of September 2001, 239 regional trade agreements (RTAs) had been notified to GATT, or its successor the World Trade Organization (WTO). Of those agreements, 100 have been notified since the creation of the WTO in 1995 after the Uruguay rRound of negotiations. A considerable number of these RTAs did not last long, however, and as of 31 January 2002, 162 agreements remained in force (Urata, 2002). With almost every nation-state having some interaction with a RTA, they are proving to be a vital part of globalization. Although, regionalism is separate from globalization, it would be hard to argue that they are not interconnected. However, and parallel to this globalization, we observe the development of a regional way, with the setting up of regional bloc, comparable to the success of the European Union (Macdissi, 2004). Macdissi explains the parallel course that regionalism is taking with globalization. One could argue that regionalism is causing the acceptance and push towards globalization. Nation-states feel safer going the course with other states rather than going it alone. This is a part of human nature "strength in numbers". I would go even farther and make a case that regionalism's ultimate output is globalization. With regionalism, I believe globalization would not be moving at the speed it is currently enjoying.

Regional trade arrangements can be further explained through contrasting and comparison. The focus has been pointed towards the four largest RTA's the EU, NAFTA, MERCOSUR, and ASEAN. "The four biggest FTA's (the EU, NAFTA, MERCOSUR, and ASEAN) accounted for about two thirds of world export trade" (Bonapace, UNESCAP). There impact and membership will undoubtedly shape the future of globalization.

\section{European Union}

The idea of European integration was conceived to prevent such killing and destruction from ever happening again. It was first proposed by the French Foreign Minister Robert Schuman in a speech on 9 May 1950. This date, the "birthday" of what is now the EU, is celebrated annually as Europe Day (www.europa.eu.int, 2005). The European Union modestly began as an economic cooperation group in 1951 under the auspices of the European Coal and Steel Community (ECSC). In 1957 these same nation-states signed the Treaties of Rome, creating the European Atomic Energy Community (EURATOM) and the European Economic Community (EEC). This loosely organized group of nation-states had a common theme to rebuild their economies after World War II. As initially explained, the EU most likely developed out of the need to allow central and western European states to continually decrease the need for US financial aid and military support, and further, to combat the threat of communism playing out in Eastern Europe. These European nation-states found it important to have somewhat of a unified voice and purpose. The Treaty of Maastricht (1992) introduced new forms of co-operation between the member state governments - for example on defence, and in the area of "justice and home affairs". By adding this inter-governmental co-operation to the existing "Community" system, the Maastricht Treaty created the European Union (EU) (www.europa.eu.int, 2005). The Maastricht Treaty, created the present form of the European Union. To further the unification, 12 of the 15 member states agreed on January 1, 2002 to merge their foreign currencies to create one currency for the entire union - the euro. Although, the euro struggled initially, it is now considered a premium currency, and many banks are switching their investments from United States' dollars to EU euros.

The European Union currently has 25 members, which in 2004 included the introduction of Cyprus, the Czech Republic, Estonia, Hungary, Latvia, Lithuania, Malta, Poland, Slovakia and Slovenia. It appears that the rest of the continent including Asian neighbor Turkey are positioning to join. With a population close to a half-billion, the EU is a large theater for global companies. As of 2003, and absent the 10 newest members, the EU controls approximately $42 \%$ of the world's merchandise imports, and $43.1 \%$ of the world's merchandise exports (WTO, World Merchandise Trade by region and selected economy, 2003). As a regional bloc, the EU is almost three times the import exporter of merchandise than the United States. The EU's sheer strength and size is pushing the world to regionalism. 
Although, the EU has made significant strides in the past 50 years, many disagreements still linger between the members states. The EU is currently mulling over the creation of a constitution. As expected, many member states are worried about losing their national identities. Unlike, the United States, the EU does not have a common language. US citizens identify themselves as Americans. That sense of national pride does not currently exists in the EU. The current struggles the EU is facing are not different from the past struggles the framers of the United States Constitution faced. This bond of European unionism will not occur overnight; however, it will eventually take a strong hold as the world continues to break up into regions. The European Union has been strategically aligning itself as a potential superpower for the $21^{\text {st }}$ century. Although, many barriers remain, the EU has come along way, and is showing no signs of slowing down.

\section{NAFTA}

The North American Free Trade Agreement is a regional trade alliance between the United States, Canada, and Mexico. A Canadian study in 1985 identified a need to negotiate a bilateral FTA with the United States. Canadian Prime Minister leveraged his relationship with then US President Reagan, and pushed for a US - Canadian FTA. The US acceded to the Canadian initiative and Mulroney and Reagan signed the US Canadian FTA in 1988 (Feinberg, 2003).

While the United States supported and initiated the eight rounds of trade talks under the General Agreement on Tariffs and Trade (GATT), the focus was not on special trading arrangements between regional nation-states. The US focus at that point in time was multilateral trade between other countries. However, once the EU became a viable competitor, the US rapidly realized the importance of regional trade partners. US trade officials recognize international power relations and the dynamics of strategic, sequential bargaining in multiple forums (Feinberg, 2003). It is my belief that the US underestimated the effects of regionalism, and pictured the future landscape of globalization minus the regionalism factor. Furthermore, the US has not been interested in trading with smaller countries with inferior modes of trade. However, the EU is proving this theory wrong. Intra and inter union trade has made the EU a viable economic force. While the French and German economies have suffered due to the inter-linking of economies with less productive states, they see their losses now as an investment in their futures. These types of scenarios have changed the United States' view of FTAs.

In January 1994, Canada, the United States and Mexico launched the North American Free Trade Agreement (NAFTA) and formed the world's largest free trade area (http://www.dfait-maeci.gc.ca/nafta-alena/, 2005). Although, the US was reluctant to initially join, it appears that the US government is pleased with the arrangement. The US is now part of the largest free trade area in the world. While FTAs are the weakest form of regional trading, it is however the first step. With movement to create the Free Trade Agreement of the Americas (FTAA) on the horizon, the US is positioning itself to remain in the world's economic driver's seat if the FTAA proposal takes off.

Among the advantages that North, Central, and South America have in common; language similarities appear to be key. Majority of both continents speak primarily three languages Spanish, English, and Portuguese. Unlike their potential American counterpart, the EU must manage a plethora of different languages. This would allow the FTAA to strategically and efficiently manage their regional agreement. However, differences do remain. Central and South American nation-states have had problems with economic and political instability. US involvement may help or hamper the potential of the Free Trade Agreement of the Americas. (FTAA).

It appears now that there are winners and losers in certain sectors of the US, Mexican, and Canadian economies. NAFTA undoubtedly had a significant stimulative effect on Mexico's exports and its receipt of foreign direct investment (Weintraub, 2004). Many argue that FTA's send high paying jobs to their inferior FTA partners resulting in job loss and lower wages. This is definitely evident in NAFTA. The United States has lost quite a few manufacturing jobs to Mexico; due to the higher wages US citizens are paid. Do I see this as a problem? Yes and no. Yes, because manufacturing is a key part of the world economy. People buy cars, computers, televisions, stereos, and other products. Nation-states need these different types of manufacturing capabilities to protect their own interests. Let the market decide, which country should support manufacturing. Furthermore, NAFTA appears to be working for each of its members. Under NAFTA, Mexico's economy is far more suitable to create cheaper manufacturing products than either the US or Canada. NAFTA is a team effort. Each member should have their own specific role as 
any economic partnership should maintain. Mexico's per capita income rose $24 \%$, to just over $\$ 4,000$ - which is roughly 10 times China's. NAFTA gave us a big push," Mexican President Vicente Fox told BusinessWeek. Fox notes proudly that Mexico's 594 billion economy is now the ninth-largest in the world, up from No. 15 a dozen years ago (Smith \& Lindbad, 2003). A developed Mexico could prove to be a beneficial partner down the road for the US.

The World Trade Organization reported in their 2003 world trade report that North America's world merchandise trade for exports was $16 \%$ and world trade merchandise for exports was $22.9 \%$. However, NAFTA does have the world's largest market. The world's largest market is currently NAFTA, which has 26 percent of the world's GNP, followed by the European Union (22 percent), China (11 percent), and Japan (8 percent) (Targowski \& Korth, 2003). NAFTA has the ability to create a spark in the Americas that no other regional trade bloc could match.

\section{MERCOSUR}

MERCOSUR, the Spanish acronym for the Common Market of the South, created by the Treaty of Asuncion among Argentina, Brazil, Paraguay, and Uruguay, has a combined GDP of about 750 billion, making it the most important regional economic arrangement after NAFTA (Weintraub, 1995). This South American regional trade bloc is the third largest regional arrangement in the world behind the EU and NAFTA. Although, the original members are developing countries with economic and political unrest, they are pooling their resources to solidify their place in the rapidly expanding global market.

The MERCOSUR common market is a unique RTA to study. While all three charter members are proactive in creating a regional trade bloc to rival all other trade blocs, they are still struggling to preserve their own existence. Recently, Argentina has been under extreme pressure to stabilize its currency. For a number of years the Argentine Peso was pegged to the US dollar, however, during a recent recession, Argentina's government abandoned the currency float. That has caused foreign investors to be leery of foreign direct investment strategies. By mid 2002, living standards had dropped by a fifth from their peak; unemployment soared to 21\% (Economist, 2005).

Brazil, another founding member of MERCOSUR has experienced some economic hardships; however, most indicators are presuming that Brazil should be out of its recession. Unlike Argentina, Brazil has not faltered on any if its public debt, which scared away investors in Argentina. Although the economy took a dive in 2001-2003, it appears that the economy is on an upswing. The positive overall outlook is a feather in President Luiz Inacio Lula da Silva's cap. Much of the recovery can be credited to his fiscal responsibility and the orthodox economic policies that few expected from a candidate who ran on a Labor Party (PT) ticket (Fittipaldi, 2005).

Chile, the final founding member of MERCOSUR has also experienced the recent economic recession of 2001-2003. Like the rest of Latin America, Chile was buffeted in the late 1990's by the jitters of investors in emerging markets. But its economy held up much better than the rest of the region (Economist, 2005). The statement goes on to state that Chile is on a road toward economic recovery. Chile's past has been vulnerable to political unrest through the rule of former dictator General Augusto Pinochet. However, Chile now has a clearer sense of democracy, which will bode well for a market economy.

MERCOSUR has similar beginnings to the EU. It originally began as a FTA, which has now graduated into a common market. The member nation-states of MERCOSUR are following the EU by establishing their own parliament. The boundary lines between these states are continually becoming blurrier and blurrier. Parliamentary representatives of the Common Market of the South (MERCOSUR) member countries and nations associated with the bloc agreed here Monday to begin "working on the creation of a joint parliament" for the region (Xinhua, 2004). One advantage MERCOSUR has over its rival trade blocs is the homogenized cultural likeness these nation-states share. Many share a common language of either Portuguese or Spanish. Furthermore, these nations were created close to the same time and share a common sense of cultural togetherness. This eliminates many of the hardships the EU has encountered with cultural differences. MERCOSUR's global market numbers pale in comparison to the EU and NAFTA, however, both the EU and NAFTA member's primarily have well-established economies, whereas, Brazil, Argentina, and Chile are still developing. Brazil and Argentina make up roughly $1.4 \%$ of world merchandise trade. 


\section{ASEAN}

The Association of Southeast Asian Nations or ASEAN was established on 8 August 1967 in Bangkok by the five original Member Countries, namely, Indonesia, Malaysia, Philippines, Singapore, and Thailand. Brunei Darussalam joined on 8 January 1984, Vietnam on 28 July 1995, Laos and Myanmar on 23 July 1997, and Cambodia on 30 April 1999 (www.aseansec.org, 2005). The nation-states who represent the South East Asian economy, similar to the members of the EU and MERCOSUR, felt that a unified regional trade agreement would propel them farther than what they could accomplish alone. This premise is the starting factor in the creation of almost every FTA agreement. Members of ASEAN share similar cultural backgrounds, which would certainly benefit any type of economic consolidation.

Unlike the other three RTA's, ASEAN has not seen a significant amount of success. ASEAN was essentially set-up originally to be a mild regional economic participation group with key economic sectors from each nation-state exempted from tariff restrictions. This policy has been updated several times, especially, when the ASEAN Free Trade Agreement (AFTA) was established in 1992. Even then special consideration was given to key economic sectors. ASEAN was moving away from FTA principles. A common effective preferential tariff (CEPT) scheme was applied in 1993, providing for the gradual reduction of tariffs on intra-ASEAN trade in certain goods over a number of years. Again, however, member states could exclude "sensitive" items, limiting progress (Country Profile, Vietnam, 2004). Without a clear move towards regional cooperation, ASEAN will find it extremely difficult to compete with other regional trade agreements.

However, different from traditional FTA's ASEAN has a keen interest in addressing security issues relevant to the member states, and a host of other states including Canada, US, EU, Japan, and China among others.

The ASEAN Security Community is envisaged to bring ASEAN's political and security cooperation to a higher plane to ensure that countries in the region live at peace with one another and with the world at large in a just, democratic and harmonious environment (www.aseansec.org, 2005). This security arrangement to some extent resembles a treaty organization such as the North Atlantic Treaty Organization (NATO). ASEAN deems to protect the interests of South East Asia. At the time of its creation regional security cooperation agreements were popular. Due to the fear surrounding the spread of Communism, many nations felt that allies or security partners could bolster their individual security.

The economic numbers for ASEAN are smaller than their North American and European counterparts; however, their numbers are greater than MERCOSUR. The World Trade Organization only ranks six of the ten members and labels them six East Asian Traders in their 2003 report on world merchandise trade by region. The six ASEAN members roughly maintain $9.7 \%$ of world merchandise exports, and $8.3 \%$ of world merchandise imports. Their exports are vital to many of the developed nations in North America and Europe. Although, their economic numbers are smaller than the larger FTA's, however, ASEAN is attracting a great deal of foreign direct investment. Global businesses use South East Asian labor to produce many of their products.

\section{Future Regional Impact On Globalization}

Previewing the four large regional trade agreements proves the vitality of the regionalism concept. The United Nations, Economic and Social Commission for Asia and the Pacific reported that the EU, NAFTA, MERCOSUR, and ASEAN combined make up two-thirds of the world's export trade (Bonapace, UNESCAP). Analysis of the regional cooperation movement, demonstrates the world's continuing push to globalize through FTA's or other means of regional collaboration. The concepts make perfect sense. People typically like to do business with reliable trustworthy partners. Nation-states are no different. Regional trade agreements provide a medium for reliable commerce to transact. Many of the arrangements are based on cultural and ethnic likeness, close proximity, and freer trade. For all the realities of globalization, nations cannot escape their own geo-history. Culture, religion, geography, ethnicity all combine to squarely place a given nation on a map surrounded by its neighbors who have been their through the millennia (Crocker, 2002). 
Many of the nation-states who voluntarily or non-voluntarily participated in World War II have a found a need to forge relationships with their neighbors. The idea of cooperation seems to run concurrent with several of the principles associated with Game Theory. The mathematical theory of games was invented by John von Neumann and Oskar Morgenstern in 1944 (http://plato.stanford.edu/entries/game-theory/\#Mot). Game Theory and Regional Cooperation seem to have the same relative birthdates. The concept surrounding Game Theory are the ideas of having options of either being cooperative or non-cooperative. Game Theory provided sound mathematics behind cooperation, and that much was to be gained through cooperation. The US military has incorporated military strategies using several of the principles of Game Theory, which were eventually refined by John Nash, and the Nash Equilibrium. The main purpose of game theory is to consider situations where instead of agents making decisions as reactions to exogenous prices ("dead variables"), their decisions are strategic reactions to other agents actions ("live variables"). An agent is faced with a set of moves he can play and will form a strategy, a best response to his environment, which he will play by (http://cepa.newschool.edu/het/schools/game.htm).

The regionalism trend appears to be accelerating. As of 2003 there were over 170 FTAs, as reported by the United Nations. Nation-states are responding to other nation-states attempts at creating regional free trade. They must create a FTA to effectively promote their products and global business. Without a FTA, I believe it would be hard for smaller countries to compete with larger developed nations. FTAs are continually changing and growing; this will continue into the future. Eventually, the entire world could become one free trade agreement. For instance, he said the EU has set a target to have 25 members by 2005, while NAFTA and MERCOSUR were targeting to combine into one economic bloc called the Free Trade Are of Americas by the same year (New Straits Time (Malaysia), 2003). East Asian nations and ASEAN members are contemplating the same conglomeration.

\section{REGIONAL TRADE BLOCS AND GLOBAL FOREIGN POLICY}

In the $21^{\text {st }}$ century, free trade arrangements are important tools of foreign policy that are intended to solidify partnerships, as military pacts did years ago (Feinberg, 2003). Foreign policy and regionalism almost appear to be one in the same now. As mentioned earlier in this paper, Game Theory could possibly explain the push to regionalism. However, I believe a chain-reaction of events have led to regionalism and globalization. After World War II, the US invested billions of dollars into the revitalization of Europe, which invoked multilateral agreements, which are still used today. Unlike 60 years ago, wars between developed nations are not practical today. This is where game theory comes in. Game Theory has proved that cooperation can have equal benefits for both sides. Pre World War II, the only way to increase national wealth was to either maintain a colony in a native land or commandeer resources from other neighboring nation-states via war. These principles are an all or nothing strategy, which is much different from Game Theory. It is unique that both Game Theory and regionalism both came to fruition during or right at the end of World War II.

Foreign policy agreements are bilateral and multilateral arrangements with an ally or allies that have several functions. Take for instance the North Atlantic Treaty Organization, member nation-states developed this alliance to combat the spread of communism into Central and Western Europe. NATO members enjoy the protection of all its allies and members. If a NATO nation is attacked by another non-NATO member, the attack will be treated as if every NATO nation was attacked. It is a one for all and all for one strategy.

The use of trade with military or treaty partners is not a new concept. The US and the EU provide cash or preferential trade agreements (PTA) to other nations. However, the US and the EU provide trade restrictions or sanctions on nation-states that do not comply with their wishes. Currently, Iran is being pushed by the US, Germany, and France to eliminate their nuclear bomb making facilities. Many times these sanctions work. Many times they do not.

Additionally, FTAs have the ability to blur borders between members. The EU is a perfect example of this concept. With the advent of their unionized currency. You can spend Euros in Greece, Spain, or Germany. Travel regulations between European Union members have been drastically reduced. The EU is moving towards becoming a borderless regional economic cooperation unit. 
The US is considering a requirement, which would require a passport to travel between Mexico and Canada. Currently a state or federal ID is satisfactory to cross the US - Canadian border, and a birth certificate and state or federal ID is the proper protocol for travel between US and Mexico. This is a step backward. The US government claims that this new requirement will halt the movement of terrorists between its borders.

Freer trade can promote and assist with the elimination of common political barriers between nation-states. FTAs are essentially the first step to a regional trade arrangement. Eventually, through evolution, a region could act, talk, and resemble a supranational country. The EU is the closest form of a supranationalist country, but NAFTA could also move into this direction. My theory is that in another 50 to 75 years this will become a reality. Nationstates will depend so much of their prosperity on their membership in a regional trade bloc that it will only seem natural to further the relationship, and create a security alliance. Indicators are pointing to this potential shift. The US is clearly seeing an advantage to membership into a FTA. US trade officials recognize international power relations and the dynamics of strategic, sequential bargaining in multiple forums. They appreciate that trade is much more than the mere exchange of goods and services. Rather trade is an instrument for influencing the balance of power within states and affecting processes of political and economic change (Feinberg, 2002). Supranationalist regions face many difficulties. Many nation-states would be hard pressed to relinquish their sovereign rights. Through regional trade this could be accomplished, with the right mix of nation-states, and the right timing.

Proximity is a key factor when looking at regionalism. From the beginning of human history, geographical proximity has been a primary condition for intersocietal commodity exchange, because distance acted as a barrier to trade (Sangmoon \& Eui-Hang, 2002). Geographical closeness provides a means for trade. The status of a regional partner creates avenues for trade within and between the regional trade arrangements. Take MERCOSUR for example, Chile, Argentina, and Brazil have much more to gain by trading as a trade bloc than they do as individual countries. However, the US essentially does not particularly need to presently be in a trade alliance, however, the future points to benefits of expansion through a trade alliance.

Level of life is another factor to consider when evaluating RTAs. Two reasons, at least, invite us to analyze the level of life in a country: The first one is the fact that a country with a high level of life gives us a good image of its development, its growth, its exchanges etc... and the second one explains that two countries having a comparable level of life, shall have intensive exchanges (Macdissi, 2004). This concept is extremely interesting. The author of the article believes that if two or more countries engaging in regional trade have similar levels of life, the trade between them will be intensive. Generally, the members of the EU, ASEAN, and MERCOSUR have similar levels of life between their members. However, the US economy is much larger than its two NAFTA partners Canada and Mexico. This could potentially create some animosity between partners. Labor unions, who were vehemently opposed to NAFTA, felt that the US had more to lose than gain by having a FTA with Mexico and Canada. There is merit in their argument.

Furthermore, the same journal article concludes with the cultural and linguistic proximity model. As I earlier mentioned, cultural and language are key factors in developing a RTA. Regional trade bloc members with common ethnicity, cultural, and language have fewer barriers to overcome than a RTA without these similarities. The customs, traditions, and cultural patrimony of the countries, imply, by their similitude a comparable way of consumption, more intensive exchanges or even a specialization and a complementarities between the concerned countries (Macdissi, 2004). Nation-states like people tend to rely on other nation-states or allies that have similar cultures or languages. For instance, the relationship among the US, Canada, Australia and the United Kingdom is far beyond a common language and the UK has given rise to the birth of the other three nations.

\section{CONCLUSION}

Regional trade blocs are a detriment to the continued expansion of globalization. This paper has shown (1) the ideology behind regionalism, (2) comparison of the four largest FTAs, and (3) the evolution of foreign policy into regional economic cooperation. Trade has been an expanding part of humankind for thousands of years. Ancient people traded through the barter system, and now people conduct business with small wireless handheld devices from thousands of miles away. The world of trade has evolved. 
The first section defines the different categories of regional trade, and provides a bit of history surrounding the push towards regionalism. My paper identifies four differing levels of regional trade. They include from loosest to strongest; (1) FTAs, (2) Custom unions, (3) Common markets, and (4) Economic unions. These are the basic forms of regional trade arrangements. The EU, NAFTA, MERCOSUR, and ASEAN identify with the different levels of regional trade cooperation.

The second section compares the four largest FTA's the EU, NAFTA, MERCOSUR, and ASEAN. Although, all four qualify as a FTA, they range in how strong their regional cooperation maintains. NAFTA has the weakest alignment with the EU having the strongest. The point the paper demonstrates is that regionalism is prevalent in all of the major world economies. Their actions have accelerated the movement of regionalism. Regionalism in turn has accelerated the movement of globalization.

The third and final section explains the role that FTAs have played in dictating foreign policy. FTA's are slowly filling the role that foreign policy treaties played in the past. Why not negotiate trade with a potential ally when you already maintain a security agreement. Security agreements and trade policy belong hand in hand. The article delves further into the internal workings of how a successful FTA must operate. It focuses in on three proximity theories, which include; (1) geographic proximity, (2) level of life proximity, and (3) cultural and linguistic proximity. The author of these theories believes that the principles may potentially predict the successes of a regional trade bloc agreement.

Successful trading is not predictable. Nation-states can and cannot profit from a mutually beneficial regional trade agreement. Much depends on luck and cohesiveness. As the world continues to break into regions, regional trade agreements will continue to be the fuel that fires the global economy.

\section{REFERENCES}

1. Association of South East Asian Nations. (2005). Retrieved on April 8, 2005, from http://www.aseansec.org/ 64.htm.

2. Bonapace, Tiziana. Regionalism, Multilateralism, and Development: An ongoing debate. United Nations Economic and Social Commission for Asia and the Pacific.

3. Crocker, Snow, Jr. \& Sullivan, P. (2002, January) Constructive regionalism: think globally, trade locally. World Paper, 1/16/2002.

4. European Union Information. (2005). Retrieved on March 29, 2005, from http://europa.eu.int/.

5. Feinberg, Richard E. (2003, July) The Political Economy of United States' Free Trade Arrangements. World Economy. 26(7), 22.

6. $\quad$ Fifty years on. (1998, May). Economist, 347(8068), 21.

7. Fittipaldi, Santiago. (2005, January) Brazil's Recovery: To Be Continued. Global Finance 19(1), 22.

8. Game Theory Information. (2005). Retrieved on April 9, 2005, from http://cepa.newschool.edu/het/ schools/game.htm.

9. Game Theory Information. (2005). Retrieved on April 9, 2005, from http://plato.stanford.edu/entries/gametheory/\#Mot.

10. Macdissi, Charbel M. (2004, March). Regionalization and Specialization: A Theoretical Contribution. Journal of American Academy of Business, 4(1/2), 471.

11. Matthews, Stephen P. \& Issa, N. (2003, May). GCC unveils customs union. International Financial Law Review, 22(5), 67.

12. Mercosur to create regional joint parliament. (2004, April). Xinhua (China).

13. N.A. (2003, August). Set time frame for realisation of East Asian Community. New Straits Times (Malaysia).

14. North American Free Trade Agreement Information. (2005). Retrieved on April 9, 2005, from http://www.dfait-maeci.gc.ca/nafta-alena/.

15. Regional Overview. (2004). Country Profile. Vietnam, 49.

16. Sangmoon, Kim \& Eui-Hang, S. (2002, December), A Longitudinal Analysis of Globalization and Regionalization Trade: A Social Network Approach. Social Forces, 81(2), 27. 
17. Smith, Geri \& Lindblad, C. (2003, December) MEXICO Was NAFTA Worth it? Business Week, 3863, 7.

18. Targowski, Andrew \& Korth, C. (2003). China or NAFTA: The World's Largest Market in the $21^{\text {st }}$ Century. Advances in Competitiveness Research, 11(1), 87

19. The Marshall Plan (2005). Retrieved on April 6, 2005, from http://usinfo.state.gov/usa/infousa/facts/ democrac/57.htm

20. Tough Deal. (2005, March). Economist, 374(8416), 12.

21. Urata, Shujiro. (2002). Globalization and the Growth in Free Trade Agreements. Asia-Pacific Review, 9(1).

22. Weintraub, Sidney. (1995, May). Latin American resurgence. Across the Board, 32(5), 56.

23. Weintraub, Sidney. (2004, June). Ten years Hence, Is NAFTA succeeding? Texas Business Review.

24. Writing the next chapter in a Latin American success story. (2005, April). Economist, 375(8420), 32.

25. World Trade Organization Information - Selected Long Term Trends (2003). Retrieved on March 29, 2005, from http://www.wto.org/english/res_e/statis_e/chp_2_e.pdf.

26. World Trade Organization Information. (2005). Retrieved on April 8, 2005, from http://www.wto.org/.

\section{NOTES}




\section{NOTES}

